\title{
Embedment Parallel to the Grain Strength of the Schizolobium amazonicum Herb Wood Specie
}

\author{
Diego Henrique de Almeida ${ }^{1, *}$, Tiago Hendrigo de Almeida ${ }^{2}$, Roberto Vasconcelos Pinheiro ${ }^{3}$, \\ André Luís Christoforo ${ }^{4}$, Francisco Antonio Rocco Lahr ${ }^{5}$
}

\author{
${ }^{1}$ Department of Civil Engineering (DECIv), Federal University of São Carlos (UFSCar), São Carlos, Brazil \\ ${ }^{2}$ Department of Materials Engineering (SMM), Engineering School of São Carlos (EESC), São Paulo University (USP), São Carlos, Brazil \\ ${ }^{3}$ Department of Civil Engineering, State University of Mato Grosso (UNEMAT), Sinop, Brazil \\ ${ }^{4}$ Centre for Innovation and Technology in Composites (CITeC), Department of Civil Engineering (DECIv), Federal University of São \\ Carlos (UFSCar), São Carlos, Brazil \\ ${ }^{5}$ Department of Structures Engineering (SET), Engineering School of São Carlos (EESC), São Paulo University (USP), São Carlos, Brazil
}

\begin{abstract}
Wood is one of the main raw materials used by man in several uses. It can be used in furniture and package industries, and also in components for building construction. For all these purposes, it is necessary to know the physical and mechanical properties of wood specie being used. Brazilian Code ABNT NBR 7190:1997, in its Annex B, presents methods for determining wood mechanical properties, among them the embedment parallel to grain. This property is important because it relates to the design of bolted and nailed joints in timber structures. This research aims to the experimental determination of embedment strength parallel to grain strength for Schizolobium amazonicum Herb, a wood specie recently used for structural purposes. Results showed that embedment strength for Schizolobium amazonicum Herb wood specie is lower when compared with traditional tropical essences, but sufficient for some structural applications.
\end{abstract}

Keywords Embedment strength, Mechanical properties, Structural members, Specific gravity, Schizolobium amazonicum

\section{Introduction}

Wood is a natural material and its species present different values of physical and mechanical properties, influenced by factors as: tree age, grain direction, moisture content [1-3]. Researches about physical and mechanical properties are developed with the aim of providing subsidies for better use of wood industry, civil construction among other sectors that can get it as a raw material $[4,5]$.

Wood can be used as structural material such in bridges, roofs, footbridges, among others, since their physical and mechanical properties are known, aiming development a design according to Standard Codes, as example Brazilian Standard Code ABNT NBR 7190:1997 [6-10].

This research was realized with Schizolobium amazonicum Herb wood specie (called also Paricá), wood specie from Amazonian Forest Region [11]. Physical and mechanical properties of this wood have been studied in recent yers with the purpose dissolving its use as na alternative material in relation to other species used in Brazil, such as Pinus and Eucalyptus genus [12, 13].

* Corresponding author:

diegoestruturas@gmail.com (Diego Henrique de Almeida)

Published online at http://journal.sapub.org/ijme

Copyright @ 2017 Scientific \& Academic Publishing. All Rights Reserved
Brazilian Standard Code ABNT NBR 7190:1997 [10] presents the recommendations for design of connections in timber structures using metal pins (nails or bolts). The parameters used for breaking a connection are embedment of the bolt in the wood or bending of the metal pin [14].

In case of embedment of the pin in the wood, Brazilian Standard Code ABNT NBR 7190:1997 [10] presentes the experimental procedure to tests on specimens to determination this mechanical property. If it is not possible to carry out the tests on specimens, the Brazilian Standard Code [10] recommends that the value of the embedment strength parallel to the grain $\left(\mathrm{f}_{\mathrm{e} 0}\right)$ be equal to the compressive strength parallel to the grain $\left(\mathrm{f}_{\mathrm{c} 0}\right)$.

Embedment parallel to grain strength is essential in evaluation of structural joints, but it's necessary to observe that some related problems can occur during procedures of nailing or bolting [11-17]. Molina et al [18] carried out tests to determine embedment strength of Pinus elliotti and Eucaliptus saligna.

This research aims to determine, in an experimental way, embedment strength parallel to grain strength for Schizolobium amazonicum wood specie, from Amazonian Forest Region. 


\section{Material and Methods}

Tests were carried out in Wood and Timber Structures Laboratory (LaMEM), Structural Engineering Department (SET), São Carlos Engineering School (EESC), São Paulo University (USP) and Department of Civil Engineering (DECiv), Federal University of São Carlos (UFSCar).

For this research was used Schizolobium amazonicum wood specie from trees planted forests in Legal Reserve of Northern Region of Brazil (Fig.1). Were prepared 18 specimens (Fig. 2), in the Standard condition of moisture content (12\%), according to ABNT NBR 7190: 1997 [10]. The tests specimens occurred in the universal testing machine AMSLER with load capacity of $250 \mathrm{kN}$. Were used metal dowel with diameter of $10 \mathrm{~mm}$.

According to ABNT NBR 7190:1997 [10], the embedment strength of wood $\left(f_{e}\right)$ is provided by the ratio between the load that causes the residual specific deformation of $2 \% 0\left(\mathrm{~F}_{\mathrm{e} 2 \% 0}\right)$ (determined graphically, Fig. 3) and square cross-section area of the specimen (A).

$$
\mathrm{f}_{\mathrm{e}}=\frac{\mathrm{F}_{\mathrm{e} 2}}{\mathrm{~A}}
$$

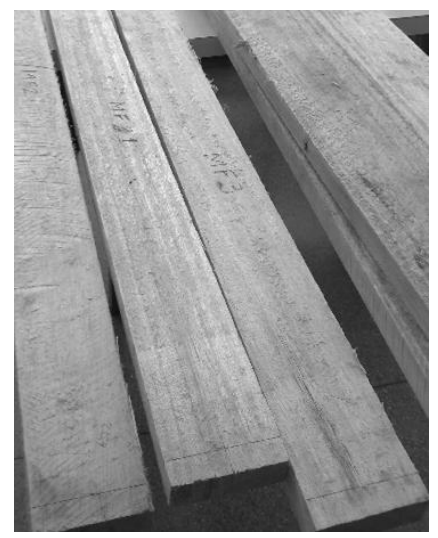

Figure 1. Members of Schizolobium amazonicum wood specie for preparation of specimens

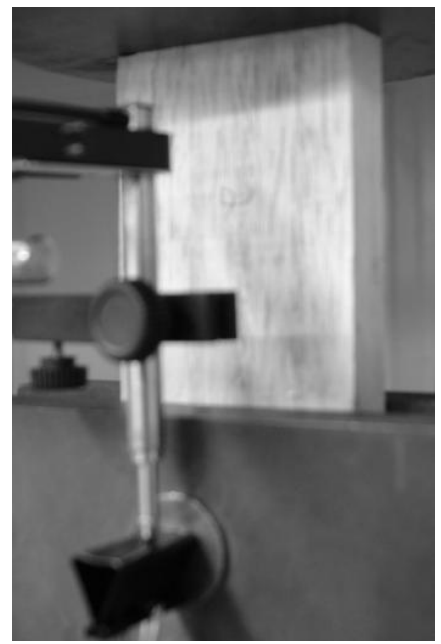

Figure 2. Standard specimen for determination embedment strength of Schizolobium amazonicum wood specie in test

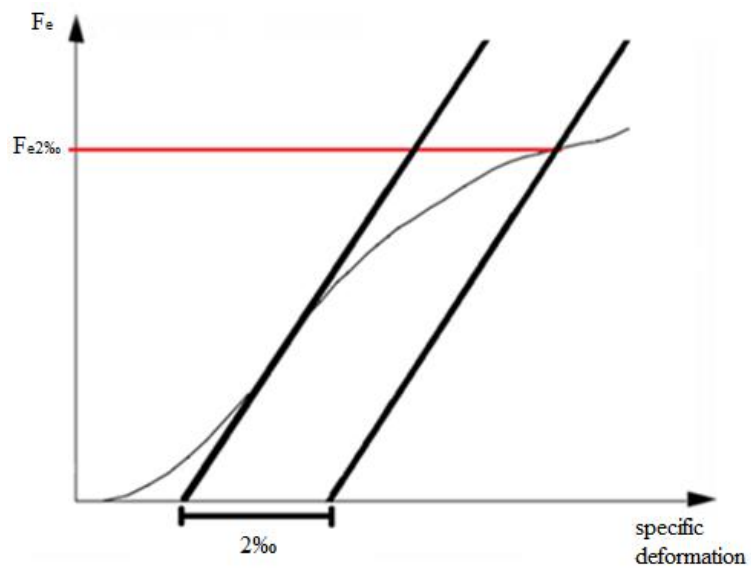

Figure 3. Embedment load vs. specific deformation to $\mathrm{F}_{\mathrm{e} 2 \%}$ determination [15]

\section{Results}

Table 1 presents the average values of embedment strength $\left(\mathrm{x}_{\mathrm{m}}\right)$, standard deviation $(\mathrm{Sd})$, coefficient of variation $(\mathrm{CV})$ and maximum (Max) and minimum (Min) values found from the Standard tests.

Table 1. Embedment parallel to the grain strength of Schizolobium amazonicum wood specie [MPa]

\begin{tabular}{cc}
\hline Statistical parameters & Values \\
\hline $\mathrm{x}_{\mathrm{m}}$ & 17 \\
$\mathrm{~S}_{\mathrm{d}}$ & 2.45 \\
$\mathrm{CV}[\%]$ & 15 \\
Max & 20 \\
Min & 13 \\
\hline
\end{tabular}

Schizolobium amazonicum wood specie is classified as strength class C20 of dicotyledonous according to the Brazilian Standard Code ABNT NBR 7190:1997 [17, 19].

Average value of the embedment parallel to the grain strength of the Schizolobium amazonicum was lower to 20 MPa. According to ABNT NBR 7190:1997 [10], embedment parallel to the grain strength can be equal to compression parallel to the grain strength, which for Schizolobium amazonicum Herb is close to $20 \mathrm{MPa}[13,15$, 18].

Embedment parallel to the grain strength found to Schizolobium amazonicum wood specie is lower compared to wood of Pinus genus [14, 15].

The low average value of the embedment parallel to the grain strength of Schizolobium amazonicum wood specie is due to the low density of wood, aproximatelly equal to 0.28 $\mathrm{g} / \mathrm{cm}^{3}[18]$. 


\section{Conclusions}

Schizolobium amazonicum wood specie present low average value of embedment parallel to the grain strength, even the wood specie being classified as C20 of the dycotiledons. More researches about mechanical and physical properties of the wood from Amazonian Forest Region are very important due to variability of wood properties.

\section{ACKNOWLEDGEMENTS}

Authors thank to Wood and Timber Structures Laboratory (LaMEM), Structural Engineering Department (SET), São Carlos Engineering School (EESC), São Paulo University, by the materials and resources used in this research. Also, thank CAPES for financial supports.

\section{REFERENCES}

[1] Calil Junior, C.; Lahr, F. A. R.; Dias, A. A. Dimensionamento de elementos estruturais de madeira. Manole, 2003.

[2] Almeida, D. H.; Scaliante, R. M.; Christoforo, A. L.; Varanda, L. D.; Lahr, F. A. R.; Dias, A. A.; Calil Junior, C. Tenacidade da madeira como função da densidade aparente, Revista Árvore, 38 (2014) 203- 207.

[3] Scaliante, R. M.; Almeida, D. H.; Macedo, L. B.; Macedo, A. N.; Calil Junior, C. Ensaio de fluência e de compressão paralela às fibras para situações da madeira à umidade de equilíbrio e saturada, Revista Madeira: Arquitetura e Engenharia, 12 (2011) 19-30.

[4] Calil Junior, C.; Molina, J. C. Coberturas em estruturas de madeira: exemplos de cálculo. Pini, 2003.

[5] Almeida, D. H.; Ferro, F. S.; Varanda, L. D.; Souza, A. M.; Icimoto, F. H.; Christoforo, A. L.; Lahr, F. A R. Quality control in plywood manufacturing: physical properties of commercal plywood of Pinus sp., International Journal of Composite Materials, 3 (2013) 163-167.

[6] Ferro, F. S.; Pigozzo, J. C.; Almeida, D. H.; Icimoto, F. H.; Macedo, L. B.; Calil Junior, C. Nondestructive evaluation of timber columns of a Capela Bridge in the state of São Paulo, Brazil, Advanced Materials Research, 778 (2013) 258-264.

[7] Andrade Junior, J. R.; Almeida, D. H.; Stamato, G. C.; Christoforo, A. L.; Lahr, F. A. R. Avaliação das condições estruturais de telhados construídos com madeira brasileira nativa, Revista Madeira: Arquitetura e Engenharia, 13 (2012) $1-10$.

[8] Andrade Junior, J. R.; Almeida, D. H.; Almeida, T. H.; Christoforo, A. L.; Stamato, G. C.; Lahr, F. A. R. Avaliação das estruturas de cobertura em madeira de um galpão de estoque de produtos químicos, Revista Ambiente Construído, 14 (2014) 75-85.

[9] Segundinho, P. G. A. Study of pedestrian-induced vibrations on timber footbridges. São Carlos, 2010, 119 p. (Doctoral Thesi's, School Engineering of São Carlos, University of São Paulo).

[10] Associação Brasileira de Normas Técnicas. ABNT NBR 7190: Projeto de estruturas de madeira. Rio de Janeiro: ABNT, 1997.

[11] Almeida, T. H.; Almeida, D. H.; Araujo, V. A.; Silva, S. A. M.; Christoforo, A. L.; Lahr, F. A. R. Density as estimator of dimensional stability quantities of Brazilian tropical woods. BioResources. v. 12. n.3, p. 6579-6590, 2017.

[12] Almeida, D. H.; Almeida, T. H.; Molina, J. C.; Ferro, F. S.; Christoforo, A. L.; Lahr, F. A. R. Embedment strength of Pinus sp. wood to metal pins, Advanced Materials Research, 884 (2014) 653-656.

[13] Almeida, D. H.; Scaliante, R. M.; Macedo, L. B.; Macedo, A. N.; Dias, A. A.; Christoforo, A. L.; Calil Junior, C. Caracterização completa da madeira da espécie amazônica Paricá (Schizolobium amazonicum HERB) em peças de dimensões estruturais, Revista Árvore, 37 (2013) 1175-1181.

[14] D. H. Almeida, Analysis of embedment and compression strenghts for Pinus and Eucalipto Wood species. Itapeva, 2011, 100 p. (Graduate Monography, Campus of Itapeva, São Paulo State University).

[15] D. H. Almeida, Proposed test method for determining of the embedment strength of wood. São Carlos, 2014, 130 p. (Master's Dissertation, School Engineering of São Carlos, University of São Paulo).

[16] Almeida, D. H.; Ferro, F. S.; Varanda, L. D.; Christoforo, A. L.; Lahr, F. A. R.; Molina, J. C.; Calil Junior, C. Comparação entre valores de ensaios experimentais e calculados da resistência ao embutimento da madeira de Pinus taeda L., Revista Árvore, 38 (2014) 347-352.

[17] Almeida, D. H.; Scaliante, R. M.; Christoforo, A. L.; Lahr, F. A. R.; Molina, J. C.; Calil Junior, C. Comparação das resistências ao embutimento paralelo às fibras de madeiras de pínus oocarpa, cumaru, pínus taeda, Revista Ambiente Construído, 14 (2014) 113-119.

[18] Molina, J. C.; Cesar, T. K.; Almeida, C. C.; Pallarolas, E. A. F. F. Emdedment strength of dowels in wood epecimens acoording to ABNT NBR 7190 (1997) and EUROCODE 5 (2004), REM-International Engineering Journal, 70 (2017) 9-1.

[19] Almeida, D. H.; Cavalheiro, R. S.; Scaliante, R. M.; Christoforo, A. L.; Calil Junior, C.; Lahr, F. A. R. Full characterization of strength properties of Schizolobium amazonicum Wood for timber structures, International Journal of Engineering \& Technology, 13 (2013) 97-100. 